$$
\begin{gathered}
\text { 심도 저체온 순환 정지를 이용한 급성 폐 색전증이 } \\
\text { 동반된 신세포암의 수술적 치료 } \\
-1 \text { 예 보고- } \\
\text { 이동협·박동춘* }
\end{gathered}
$$

영남대학교 의과대학 흉부외과학교실, 비뇨기과학교실*

\title{
Surgical Treatment of Renal Cell Carcinoma with Acute Pulmonary Embolism Using Deep Hypothermic Circulatory Arrest - A Case Report-
}

\author{
Dong Hyup Lee, Dong Chun Park* \\ Department of Thoracic and Cardivascular Surgery, and Department of Urology* \\ College of Medicine, Yeungnam University, Daegu, Korea
}

\section{- Abstract-}

Renal cell carcinoma occasionally invades the inferior vena cava and rarely extends to the right atrium and occurred massive pulmonary embolism. A healthy 54-year-old man presented to the emergency room with anterior chest pain, dyspnea and hypotension from which he had been suffering for several hours. We diagnosed him as left renal cell carcinoma with acute both pulmonary arteries embolism. The patient underwent a complex surgical procedure in which left radical nephrectomy, inferior vena cava thrombectomy and both pulmonary arteries thromboembolectomy under deep hypothermic circulatory arrest. Total circulatory arrest time was 44 minutes. We should use many inotropic agents for weaning of cardiopulmonary bypass. The patient had many postoperative complications including of acute renal failure, respiratory distress and sepsis. He died from septic shock and multi organ failure at 36th postoperative day.

Key Words: Renal cell carcinoma, Acute pulmonary embolism, Deep hypothermic circulatory arrest 


\section{서 론}

급성 폐 색전증은 발전된 진단 방법과 치료 방법에도 불구하고 높은 사망률을 보이고 있 다. 암 환자에게 있어 호흡부전의 원인 중 폐 종양 색전증은 드물다. 이런 폐종양색전증은 환자의 병 경과 과정 중 언제든지 발생가능하 다. ${ }^{1)}$ 신세포암종의 경우 때때로 하대 정맥으로 퍼지며, 우심방도 침범하기도 한다. ${ }^{2)}$ 광범위한 폐종양색전증을 가진 환자는 드물게 진단된다. 비록 폐종양색전증의 경우 혈전 용해술이 미국 식품의약국에 의해 인정받기는 하였으나, 최근 연구들에서 출혈성 부작용이 있는 혈전 용해술 이 90 일 경과 사망률을 줄이지는 못한다고 한 다." 그리고, 카테터색전제거술의 경우 모든 색전물질들을 제거하지 못하며, 오히려 만성폐 고혈압의 발생 위험성을 증가시키는 것으로 알 려져 있다. 평소 건강하게 지내오던 54세 남자 환자가 내원 수시간 전부터 발생한 흥통 및 호 흡곤란을 주소로 본원 응급실을 내원하였다. 내원하여 시행한 검사 상, 급성 양측성 폐종양 색전증을 동반한 신세포암으로 진단되었으며, 생체 징후가 불안정하며 많은 양의 강심제 사 용하였으나, 수축기 혈압이 감소하였고 동맥혈 검사 상 저산소증이 심해져 응급 수술을 시행 하였다. 수술은 심도 저체온을 이용한 순환 정 지 하에 좌측 콩팥제거술 및 양측 폐동맥의 혈 전색전제거술 및 혈전내막제거술을 시행하였다.

\section{증 례}

평소 건강하게 지내던 54 세의 남자 환자가 수 시간 동안의 흉통과 호흡곤란을 주소로 응 급실로 내원하였다. 환자는 외상이나 수술의
과거력이 없었으며, 혈전색전증의 가족력 또한 없었다. 이학적 검사 상 빈맥과 빈호흡이 있었 다. 혈압은 $70 / 40 \mathrm{mmHg}$ 였으며, 심부정맥혈전 증의 증거는 없었다. 동맥혈 검사에서는 산소 분압이 $64 \mathrm{mmHg}$, 산소 포화도는 $91.8 \%$ 로 저 산소증이 있었으며, 전혈구 검사에서는 21 $\mathrm{mm} / \mathrm{h}$ 로 적혈구침강속도가 증가되어 있었다. 생화학적 검사에서는 $\mathrm{D}$-dimer가 $40.6 \mu \mathrm{g} / \mathrm{ml}$ 으 로 증가되어 있었으며, Troponin T와 I가 각각 $0.189 \mathrm{ng} / \mathrm{ml}$ 와 $7.36 \mathrm{ng} / \mathrm{ml}$ 로 증가되어 있었 다. 흥부전산화단층촬영에서 좌측 신장에 조영 증강이 되는 종괴가 관찰되었으며(Fig. 1), 양 측 폐동맥에 색전증이 관찰되었다(Fig. 2). 심 장초음파에서는 운동감소가 있는 우심실 비대 가 관찰되며 중증도의 폐동맥고혈압 $(\mathrm{RVSP}=36$ $\mathrm{mmHg}$ )이 관찰되었다. 그리고 우심방 및 우심 실에는 종괴의 소견은 없었다. 환자는 조직플 라스미노겐활성제(tissue plasminogen activator) 와 저분자량 헤파린(low-molecular-weight heparin) 을 사용하였으며, 도파민과 인공혈장증량제를 정맥으로 주입하였다. 환자의 혈역학적 상태가 안정되지 못해 응급 수술을 결정하였다. 좌측

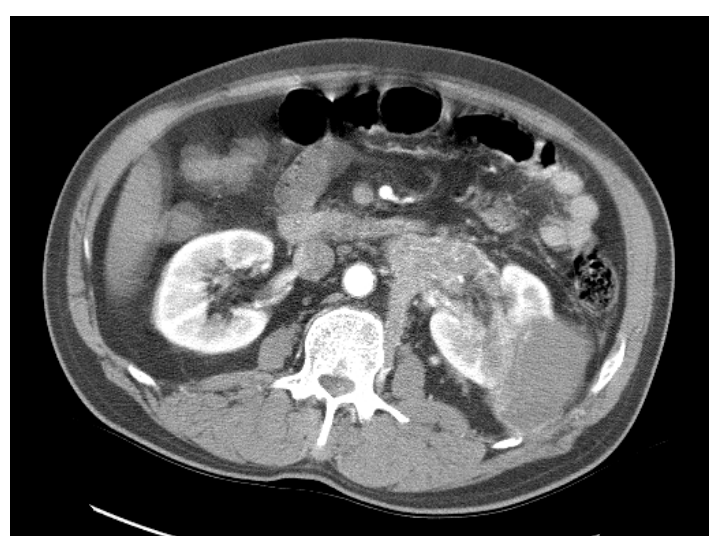

Fig. 1. About $5 \mathrm{~cm}$ sized heterogenous mass at left kidney. 


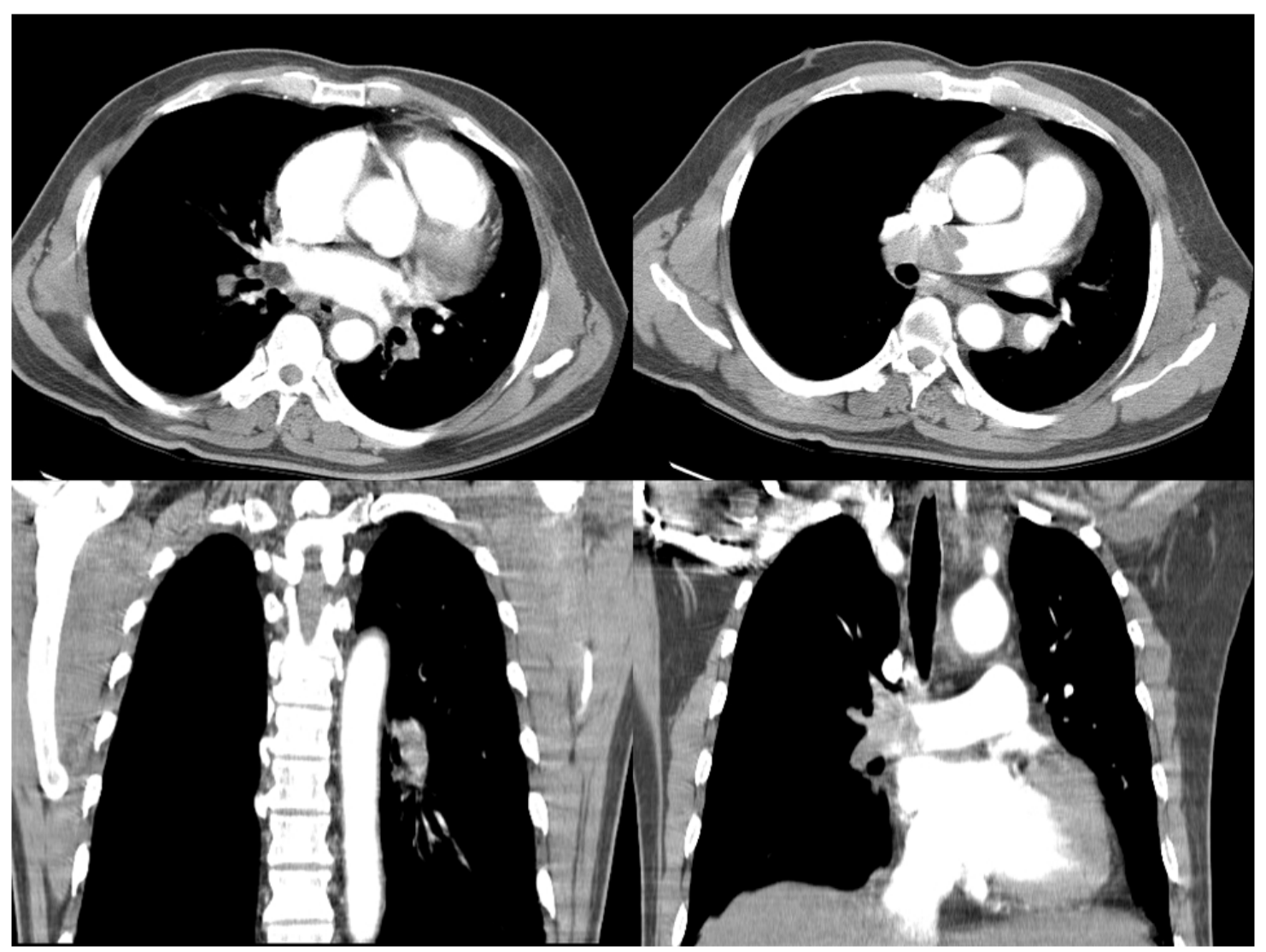

Fig. 2. Chest CT shows multifocal filling defects at both main pulmonary arteries and its branches.

근치적 신장절제술과 하대정맥의 혈전제거술을 시행하였으며, 양측 폐동맥의 색전혈전제거술 을 시행하였다. 근치적 신장절제술을 위해 개 복술을 시행한 후 혈역학적 상황이 더 나빠졌 다. 그래서 부분 체외순환술 하에 근치적 신장 절제술을 위한 좌측 신장 동맥을 제외한 주위 의 조직들을 박리한 후, 전체 체외순환을 시행 하면서 중심 체온을 $20^{\circ} \mathrm{C}$ 까지 낮춘 후 순환 정지를 시켰다. 14 분 동안의 순환 정지 하에 근치적 좌측 신장절제술과 Fogarty 도관을 이 용한 혈전제거술을 시행하였다. 신장절제술이 끝난 뒤, 재순환을 하였으며 우측 폐동맥 주위 를 박리하였다. 박리가 끝난 뒤 10 분간의 순환
정지 하에 우측 폐동맥에 세로 절개를 한 뒤 혈전을 제거하였으며, 그 후 재순환을 하였다. 좌측 폐동맥을 주위 조직과 박리한 후 노출시 키고 20분간의 순환 정지를 시행하였다. 수직 절개를 한 뒤 혈전색전제거술을 시행하였으며 폐동맥내막절제술을 함께 하였다. 환자는 인공 심폐순환을 이탈시키는데 있어서 어려워 암리 논(amrinone), 에피네프린(epinephrine), 도파민 (dopamine)을 사용하면서 수축기 혈압이 80 $90 \mathrm{mmHg}$ 유지되면서 인공 심폐순환을 종료 하였다. 수술 직후 소변량이 줄면서 급성 신부 전이 발생하여 혈액투석을 시행하였다. 수술 후 병리학적 소견으로 절제된 신장의 절단면 


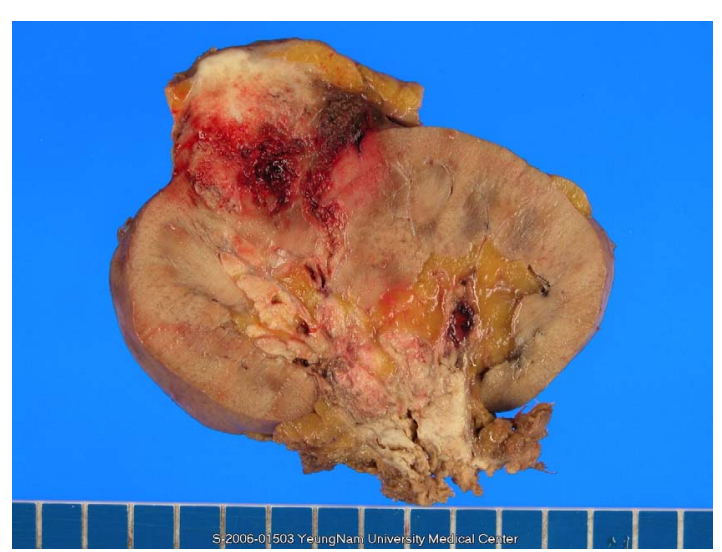

Fig. 3. The kidney shows an ovoid mass lesion in peripheral portion of the upper pole area. The cut surface of the mass shows variegated appearance with multifocal hemorrhage and necrosis. The mass is extending to the perirenal fat tissue through the renal capsule.

(Fig. 3)은 위쪽 부분의 가장 자리에 난원형의 종괴가 보였다. 그 종괴는 출혈과 괴사로 인해 얼룩덜룩하게 보였다. 그리고 피막을 침범하여 신장 주위 지방 조직까지 연결되어 있었다. 폐 동맥 색전술 후 혈전(Fig. 4)에서는 신세포암 에서 기시한 종양 색전이 관찰되었다. 수술 후 9일째 환자는 인공호흡기를 이탈하였으며, 수 술 후 13 일째 환자가 흑색 변을 봤으며 위내시

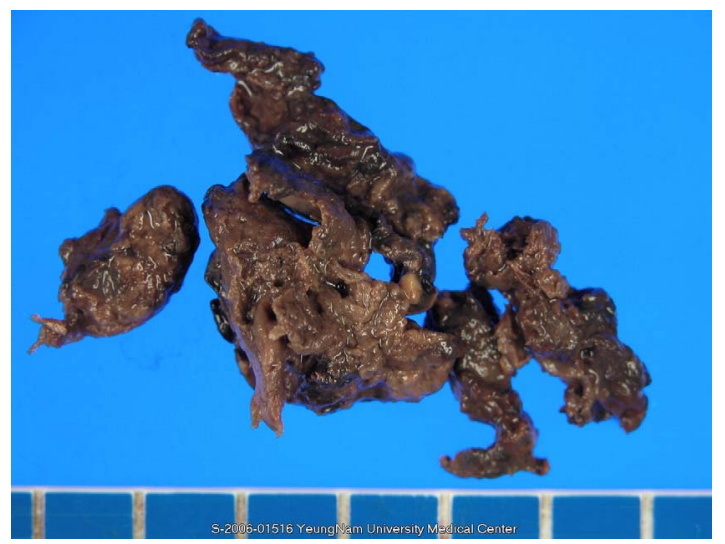

Fig. 4. Thrombus with bits of tumor emboli(clear cell renal cell carcinoma).
경 상 궤양 출혈이 있어 지혈술을 시행하였다. 수술 후 32 일째 환자는 인공호흡기를 이탈하였 다가 34 일째 저혈압이 발생하면서 호흡부전이 동반된 패혈성 쇼크(septic shock)로 인해 기관 내 삽관을 하였다. 수술 후 36 일째 혈압이 유 지되지 않으며 다발성장기기능부전으로 인해 사망하였다.

\section{고 찰}

신세포암은 정맥순환계통으로 전이하는 경 향이 높다. 신장 정맥과 하대 정맥으로 전이되 는 경우는 각각 $33 \%$ 와 $6 \%$ 정도이다. ${ }^{4)}$ 그러나 우심방이나 우심실로의 전이는 드물다. 폐동맥 으로 전이되어 색전증이 발생하는 경우는 더욱 드물지만 매우 위험하며 많은 사망의 원인이 되기도 한다. 폐종양색전증은 고형종양으로부 터 떨어져 나온 각각의 세포 혹은 세포 덩어리 가 체순환을 통해 파급되어 발생되는 것으로 생각되어진다. ${ }^{5)}$ 폐종양색전증의 발생에는 두 가지의 경우가 있다. 첫 번째의 경우는 큰 종 양색전으로 인해 주 폐동맥이나 큰 가지가 일 부 혹은 완전히 막힌 경우이며, 두 번째의 경 우에는 좀 더 작은 종양색전으로 인해 작은 동 맥이나 세동맥들이 서서히 막히는 경우이다. 이 두 가지가 동시에 일어날 수도 있다. ${ }^{5-7)}$

급성폐색전증은 호흡곤란, 저산소증이 동반 된 흥통, 혈역학적으로 불안정한 급성 폐성심 등의 증상을 보인다. 폐종양색전증을 사망 전 에 진단하기는 매우 어렵지만, 부검에서 발견 하기는 어렵지 않다. 악성 종양을 가진 환자들 에서 그 발생률은 $1 \%$ 에서 $26 \%$ 로 다양하게 보 고되고 있다. ${ }^{1)}$ 폐색전증의 치료 방법에는 헤파 린을 이용한 항 응고 치료법, 혈전 용해법 그 
리고 수술 혹은 도관을 이용한 색전 제거술 등 이 있다. International Cooperative Pulmonary Embolism Registery의 연구 결과에서 폐색전 증에 있어 하대 정맥 필터가 90 일 경과 사망률 을 의미있게 낮춘다고 보고되고 있다. ${ }^{8)}$ 그러나 가장 최적의 치료법에 대해서는 아직 논란이 많다. 급성기의 치료는 호흡 부전과 순환 부전 의 개선과 재발의 방지를 목표로 한다. 혈전 용해술을 시행받은 환자들 중 $4.9 \%$ 그리고 헤 파린을 이용한 항 응고 치료법을 시행받은 환 자들 중 $9.3 \%$ 에서 재발로 인해 사망하였다. ${ }^{9}$ 급성 폐 색전증 환자들의 치료에 있어 많은 전 향적 연구에서 수술과 내과적 치료를 비교하였 으며, 내과적 치료를 받은 환자들이 더욱 높은 사망률과 재발률을 보였다. ${ }^{10)}$ 이것은 수술과 혈전 용해술을 비교한 최근의 전향적인 연구에 서 확인되었다. ${ }^{11)}$ 혈역학적으로 불안정한 환자 의 경우 수술적 색전제거술이 주 치료법으로 최근 선호되고 있다. 그리고 혈역학적으로 안 정된 환자의 경우 수술적 색전 제거술이 즉각 적이고 가장 확실한 치료법이며, 장기간의 결 과에 있어서도 우수했다. ${ }^{12)}$ 급성폐색전증의 경 우 높은 사망률을 보이며 특히 혈역학적으로 불안정한 환자의 경우 더욱 높다. 혈전 용해술 의 경우 출혈에 따른 합병증 발생 가능성이 높 아서 급성 폐 색전증 환자의 경우 조기 진단에 따른 수술적 색전 제거술이 반드시 필요하다.

혈역학적으로 안정되지 않은 경우 장기간의 체외순환으로 술 후 심근 기능 저하로 심폐기 이탈이 어려워 강심제를 사용 후 심폐기 이탈 에는 성공하였으나 신기능 부전 등 여러 합병 증의 발생으로 중환자실에서 장기간 집중 치료 후 사망한 환자를 볼 때, 혈역학적 안정을 위 한 신절제와 폐색전증 제거의 수술 시간의 단
축 등이 보다 나은 술 후 결과를 가져올 것으 로 생각한다.

\section{참 고 문 헌}

1. Veinot JP, Ford SE, Price RG. Subacute cor pulmonale due to tumor embolization. Arch Pathol Lab Med 1992 Feb;116(2):131-4.

2. Kubota H, Furuse A, Kotsuka Y, Yagyu K, Kawauchi M, Saito H. Sussessful management of massive pulmonary tumor embolism from renal cell carcinoma. Ann Thorac Surg 1996 Feb;61(2):708-10.

3. Kucher N, Rossi E, De Rosa M, Goldhaber SZ. Massive pulmonary embolism. Ciculation 2006 Jan 31;113(4):577-82.

4. Marshall VF, Middleton RG, Holswade GR, Goldsmith EI. Surgery for renal cell carcinoma in the vena cava. J Urol 1970 Apr;1970(4): 414-20.

5. King MB, Harmon KR. Unusual forms of tumor embolism. Clin Chest Med 1994 Sep; 15(3):561-80.

6. Rossi SE, Goodman PC, Franquet T. Nonthrombotic pulmonary emboli. Am J Roentgentol 2000 Jan;174(6):1499-508.

7. Shepard JAO, Moore EH, Templeton PA, McLoud TC. Pulmonary intravascular tumor emboli: dilated and beaded peripheral pulmonary arteries at CT. Radiology 1993 Jan;187(3):797801.

8. Decousus H, Leizorovicz A, Parent F, Page Y, Tardy B, Girard P, et al. A clinical trial of vena caval filters in the prevention of pulmonary embolism in patients with proximal deep vein thrombosis. New Engl J Med 1998 Feb 12;338 (7):409-15.

9. Thabut G, Thabut D, Myers RP, BernardChabert B, Marrash-Chahla R, Mal H. 
Thrombolytic therapy of pulmonary embolism: a meta-analysis. J Am Coll Cardiol 2002 Nov;40(9):1660-7.

10. Gulba DC, Schmid C, Borst HG, Lichtlen P, Dietz R, Luft FC. Medical compared with surgical treatment for massive pulmonary embolism. Lancet 1994 Mar 3;343(8897):576-7.

11. Meneveau N, Seronde MF, Blonde MC, Legalery
P, Didier-Petit K, Briand F, et al. Management of unsuccessful thrombolysis in acute massive pulmonary embolism. Chest 2006 Apr;129(4): 1043-50.

12. Digonnet A, Moya-Plana A, Aubert S, Flecher E, Bonnet N, Leprince P, et al. Acute pulmonary embolsim: a current surgical approach. Interact Cardiovasc Thorac Surg 2007 Feb;6(1):27-9. 